\title{
INDEXES
}

\section{Index of Subjects and Names}

\section{A}

Abraham Bibago- on corporeal form 589.

Abraham Ibn Daud-and Maimonides 323; Emunah Ramah used by Crescas 22 ; infinite magnitude $347,354-$ 355 ; infinite number 476,481 ; definition of quantity 418 ; enumeration of discrete and continuous quantities 420 ; implied criticism of Saadia and Ibn Gabirol 420 ; meaning of 'position' 689 ; meaning of 'relation in position' 689; the four elements not moved by themselves 671; nature the cause of the motion of the elements 672 ; enumeration of four categories of motion 502; circular motion is motion in position 505 ; as immediate source of Crescas' discussion of matter and form 570 ; deduction of the opposition of matter and form 572 ; relativity of the terms matter and form 579; corporeal form 587-588; why matter is substance 573 ; why form is substance 574 ; enumeration of six substances 575-576; on Ibn Gabirol's universal matter 599, 600-601; spheres are composed of matter and form 598; motion of the spheres is voluntary 535; accidents 576. See also Index of Passages.

Abraham bar Hiyya-his versions of Aristotle's definition of time 638, 639,640 ; time not a substance 641 ; time partly real and partly ideal 661-662. See also Index of Passages.

Abraham Shalom-criticizes Crescas for not mentioning authorities 6 ; analogy between the problems of the identity of the Sefirot and of the prime mover with God 461-462; on Maimonides' view as to the hylic intellect 607; refutes Crescas on the measurability of time by rest 649 ; whether the spheres are composed of matter and form 598. See also Index of Passages.

Abravanel, Isaac,- - his commentary on Moreh 27; on Maimonides' ignorance of Averroes 323; on Crescas' ignorance of Algazali's and Averroes' Tahafut 16-17; on Crescas' knowledge of Algazali's Makassid 11, n. 48; prime matter 600 ; cor poreal form $580,584,585,589-590$; reference to Leo Hebraeus 600 ; assigns Platonic source to Avicenna's theory as to the composition of the spheres of matter and form 597. See also Index of Passages.

Absolute-relative - Hebrew and Arabic terms for 497-498.

Abu 'Imran Moses Tobi 459, 501.

Accident-general and particular sense of the term 99,577 ; meaning of accident 103,576; accident and form 259,263 ; forms are accidents according to Kalam 570 ; classification of accidents 103, 307, 686-687; divisibility of accidents 104-105, 265, 602-603; cannot exist apart from corporeal objects 666; the accidental is only possible 82,249 , 551. See also Accidental Motion under Motion.

Accidental - two meanings of the term 434. 
Action and passion-whether there is motion in the categories of action and passion 72, 231, 506, 513.

Actuality and potentiality-cause of transition from potentiality to actuality must be external $89-90$, 299-301,676-679; why creation does not imply a transition from potentiality to actuality in God 90, 303, 679; Maimonides' explanation differs from that of Crescas 679-680.

Air - has relative motion upward 141 , $161,337,412$; is relatively light and heavy 239,412 ; its relation to fire 450; has weight in its own place 539; different explanations as to why it descends into a ditch 185 , $239,412-414$; its relation to fire 450.

Albalag, Isaac,- - why air descends into a ditch 413.

Albertus Magnus 343.

Albo, Joseph,-re-echoes class-room discussions of Crescas 30; the Sefirot 459; criticism of Aristotle's definition of place 448, 457; answers Aristotle's objection to the identification of place with vacuum 443; identifies place with vacuum 455 ; the proper place of earth 446,456 ; the place of the outermost sphere 440; outside the universe there is 'nothing' 115,422 ; time 656,558 ; existence of time prior to creation 663-664. See also Index of Passages.

Alexander of Aphrodisias - and Maimonides 322 ; his commentary on the Physics known to Crescas through Averroes 9; outermost sphere does not exist in place 437; outermost sphere immovable 433, 437 ; spheres not composed of matter and form 596; every motion is in time 543; magnetic attraction 563; Plato's view on time 635 ; the hylic intellect 606; immortality of the soul 667 ; his title for the Posterior Analytics 526.

Alfarabi-both commentator and author 322; and Maimonides 323, 570; corporeal form 586; place of the spheres 434 ; spheres not composed of matter and form 596. See also Index of Passages.

Algazali-and Maimonides $323 ; \mathrm{Ma}$ kaşid used by Crescas 10 ; Hebrew translations of the Makassid 10, n. 44; Makassid popular text-book among Jews 10 ; refutation of the view as to the influence of the Tahafut on the Or Adonai 11-18; arguments against infinite magnitude $347,384,386$; infinite number $477,478,488-489$; infinite number of causes and effects $483,493,496$; infinite number of disembodied souls 484-485, 486; essential and accidental infinite causes 494; his version of Aristotle's definition of place 362 ; the proper places of the elements 445 ; the four categories of motion 502, 504-505. in what sense motion is to be found in all the ten categories 517 ; qualitative change is in no-time 464; quantitative change involves locomotion 520; accidental and participative change 531-532; the four elements not moved by themselves 671 ; form is the cause of the motion of the elements 673 ; contends that the motion of the spheres is natural and not voluntary 536; enumerates four continuous quantities 420 ; his versions of Aristotle's definition of time 639,640 ; classification of theories as to composition of body 569 ; arguments against atomism 570; deduction of the opposition of matter and form 592; matter recognizable only in thought 591 ; two meanings of the term 'form' 573-574; corporeal form 585-587; definition of substance 573 ; why form is sub- 
stance 573-574; enumeration of four substances 575 ; two meanings of the term 'accident' 577 ; classification of accidents 686 ; the accidents of 'smooth-rough' and 'rare-dense' 688; universals 665-666; meaning of 'relation' 689; of 'position' 690' threefold classification of arguments 397; spheres composed of matter and form 595; admissibility of positive attributes 14. See also Index of Passages.

Alkindi-first of Moslem philosophers 321 ; enumerates six species of motion 500.

Altabrizi-commentary on the twenty-five propositions 1, 2, 3; contemplated commentary on the entire Moreh 19, n. 65; characterization of the anonymous translation of his commentary 19-21; the anonymous translation quoted $20,21,381$, $382,384,484$; Isaac ben Nathan's translation used by Crescas 21; extent to which Altabrizi was used by Crescas 22-23; his three arguments against an infinite magnitude $3,346,381,384,386-387$; infinite number 477; distinction between number of magnitudes and number of incorporeal beings 480 ; infinite number of causes and effects 482 483 ; infinite number of disembodied souls 484; distinction between a force infinite in intensity and a force infinite in time 613 ; three definitions of motion 525 ; the four categories of motion 505 ; in what sense motion is to be found in all the ten categories 507,517 ; change in substance is in no-time 503; circular motion is motion in position 505 ; locomotion is involved in quantitative motion, but is imperceptible 521; terms motion and change not convertible 522; classification of motion and change 532; accidental and partici- pative motion 534; what kind of accidental motion cannot be eternal $551 \mathrm{f}$.; whether the four elements are moved by themselves 670-671, 674 ; deduction of the opposition of matter and form 593; arguments against atomism 570 ; corporeal form 585 ; classification of various views on time 635; version of Aristotle's definition of time 637 ; why time is described as having necessary existance 662 ; meaning of the expression passing from potentiality to actuality 676-678; meaning of 'position' 689,690 ; two senses of the term 'possible' 698. See also Index of Passages.

Alteration - motion in respect to quality 500-501, 627-628. See also Motion.

Anaximander -innumerable worlds in an infinite void 118; denial of distinction of above and below 463 .

Ancient-to what philosophers applied 320-321.

Anger 547, 548.

Animal-cause of the motion of 297.

Apollonius 52,465.

Appetite 547.

Arama, Isaac, 538.

Arguments-classification of the various types of arguments 326, 337, 397.

Aristotle-referred to as "the Greek" 539; acclaimed as superior to all other philosophers 325 ; evidence of an oral interpretation accompanying Aristotle's writings among Jews and Arabs 7-8; Crescas' knowledge of Aristotle 7; impossibility of infinite magnitude $40-41,43,49-50,51$; impossibility of infinite number 65 , 476; impossibility of infinite causes and effects 65,482 ; impossibility of a vacuum $54,55,56,59$; finitude of the universe 115; impossibility of many worlds 117 , 473-474; differ- 
ence between place and space 116, 352 ; definition of place 44, 362; variety of Arabic and Hebrew versions of his definition of place 362365 ; his theory of proper places 45 , $445-446$; as to what is the proper place of earth $445-446$; as to the place of the spheres and the universe 45, 432 ff.; distinction between change and motion 70,498; his two definitions of motion 75,511 ; his enumeration of the categories of change and motion $498 \mathrm{ff}$.; as to the category of circular motion 505 ; as to motion in the categories of action, passion and relation 506; his classification of motion and change 76 , 531; meaning of accidental motion 534 ; on the motion of pleasure and pain 448,449 ; as to whether motion is involved in the act of thinking $547,548,549$; the nature of the circular motion of the spheres 537; on time $634 \mathrm{ff}$.; his treatment of the problem of time $94-95$; his enumeration of the views of his predecessors on time 634; variety of Arabic and Hebrew versions of his definition of time 636-640; on the transformation of the elements into one another 450 ; his enumeration of the views of his predecessors on the composition of bodies 570; his deduction of the opposition of matter and form 99, 571; matter recognizable only in thought 591 ; his definition of substance 102, 573; why matter is substance 103, 573; why form is substance 103,573 ; his enumeration of substances 575 ; distinction between possibility and necessity 109110 ; distinction between potentiality and possibility 111-112, 691-692; the nature of the substance of the spheres 596; his theory of lightness and weight and of upward and downward motion 58-59, 78-79,
$337-338,410-411$; as to the weight of air 539; his enumeration of discrete and continuous quantities 420 ; his definition of truth $324,456-$ 457. See also Index of Passages.

Ashkenazi, Saul ha-Kohen, 589.

Asymptote 52.

Atomists-called 'ancient' by Maimonides 321 ; vacuum $54,344,400$; identification of space with vacuum 356; characteristic features of atomism 120-121, 569-570; Crescas' revival of atomism 121; magnetic attraction 563; innumerable worlds in an infinite void 118 .

Attributes-admissibility of positive divine attributes 13-14; of extension and thought 122-123.

Avempace-mentioned by Crescas 5; known to Crescas through Averroes 9; his theory of original time of motion 57, 183-185, 205, 271, 404ff., the place of the spheres and the universe $434,438,449$; motion of the spheres natural and not voluntary 537; everything movable is divisible 544 ; on possibility and potentiality 691 .

Averroes-and Maimonides 323; Jewish Averroism different from scholastic Averroism 31; which of his commentaries used by Crescas 8-10; his Tahafut al-Tahafut unknown to Crescas 11-18; method of Jewish commentaries on Averroes 27; his use of the expression "he said" 329 ; analysisof argumentsagainst infinite magnitude 39 , n. 2 ; why an infinite magnitude must be infinite in all dimensions 429-430; infinite number 477,489 ; division of number into even and odd $219,477,489$; distinction between infinite spatial things and infinite non-spatial things 486487 ; infinite number of disembodied souls 488 ; infinite number of causes and effects 482, 492; essential and 
accidental causes 494-495; distinction between a force infinite in intensity and a force infinite in time 612-614; version of Aristotle's definition of place 362,364 ; the proper place of earth $445 \mathrm{ff}$.; place of the spheres and the universe 433ff., 438ff., 449; outside the universe there is 'nothing' 115,421 ; definitions of motion 523-524, 529530 ; categories of motion 507; the two subjects of motion 510-511; circular motion not motion in position 506; refutation of Avempace's theory of original time of motion 404ff.; the medium an inseparable condition of motion 409-410; acquisition of knowledge is in no-time 548 ; elements not moved by themselves but by something external to themselves 673-674; Intelligences not moved accidentally 608 ; relation of the Intelligences to the spheres 606; spheres possess no soul in addition to the Intelligences 607 ; what sort of accidental motion cannot be eternal 553 ; impenetrability of bodies 415; deduction of the opposition of matter and form 571 ; corporeal form 585-587; spheres not composed of matter and form 103, 261, 594-597; version of Aristotle's definition of time 636,638 ; the Intelligences not related to each other as causes and effects 667; immortality of the soul 487, 667; relation of the hylic and acquired intellect to the body 608 ; possibility and necessity $111,561,680$; meaning of necessary existence 111,681 ; two meanings of the term possible 697 ; magnetic attraction 566; God identified with 'prime mover' 608; See also Index of Passages.

Avicebron-see Ibn Gabirol.

Avicenna-and Maimonides 323; first and foremost among Moslem phi- losophers 321 ; known to Crescas through secondary sources 10 ; arguments against infinite magnitude 347,383 ; distinction between infinite spatial things and infinite nonspatial things $477,486-487$; infinite number of disembodied souls 485 , 486 ; infinite number of causes and effects 482-483; circular motion is motion in position 439, 505, 506; only four categories of motion 507; his enumeration of the four categories of motion 71,507 ; form is cause of the motion of the elements 673 ; motion of the spheres is voluntary motion 535 ; change in substance is in no-time 503; explanation of upward motion 412; nature's abhorrence of a vacuum 413; deduction of the opposition of matter and form 591 ; corporeal form $582-585$; spheres composed of matter and form 103 , $261,594,597$; possibility and necessity $110,111,561,680-682$; the Intelligences are related to each other as causes and effects 666-667; immortality of the soul 667; God not identified with 'prime mover' 110. See also Index of Passages.

Azriel 459, 460.

\section{B}

Bacher, W., 458, 465.

Bacon, Francis, 347.

Bacon, Roger, 126, 347.

Bahya ben Asher 460.

Bahya Ibn Pakuda - impossibility of an infinite number of causes and effects 492; spheres composed of matter and form 598. See also Index of Passages and PseudoBahya.

Barthelemy-Saint-Hilaire, J., 352.

Bedersi, Jedaiah, 2.

Below-see Above.

Ben Daud-see Abraham Ibn Daud.

Benvenisti ibn Labi, Don., 12, n. 49. 
Bergh, S. van den, 482, 589.

Bergson, H., 97.

Bibago-see Abraham Bibago.

Body-definition of 541, 590; cannot be infinite 151-157, 347-365; impenetrability of bodies $187,415-$ 416; meaning of 'simple bodies' 337; everything movable and divisible is a body 241; a body moving another body is moved itself 255; how accidents and natural form are said to exist in body 257; certain things existing in body are divisible with the body 263; one of the continuous quantities 419 .

Bonaventura (St.), J. F., 654.

Brethren of Purity-see Ihwan al-Safa. Broyde, I., 11, 461, 500.

Bruno, Giordano,- - similarities with Crescas 35-36, 118; air has weight 414 ; action of infinite in finite time 466 ; infinite has neither middle nor end 472 ; infinite neither heavy nor light 431 ; infinite is immovable 464 ; distinction between a force infinite in extension and a force infinite in intensity 613 ; infinite is figureless 470; universe not finite 115 ; outside the world there is a vacuum 422 ; Aristotle's definition of place does not apply to outermost sphere 443 ; many worlds 476; distinction between 'mixture' and 'inexistence' 560. See also Index of Passages.

\section{C}

Care and pleasure 247.

Carra de Vaux, B., 347, 483, 485, 486, $489,535$.

Carrying 562.

Caspi, Joseph, 323.

Category-see Substance, Quantity, Quality, Relation, Place, Time, Position, Action, Passion, and also under Motion.

Cause-essential and accidental 54,
66-67, 494. See also under Infinite and under Motion.

Causeless-identified by Avicenna with necessary per se 110-111.

Centre-special meaning of term when applied to earth 432, 451-454.

Change-see Motion.

Chrysippus 639.

Circular motion - see Motion and Infinite.

Cold-see Hot.

Conic Sections, Book on, 207, 465.

Contiguous - defined by Aristotle 376.

Continuous - the two meanings of the term 275, 617. See also Quantity.

Contraposition, conversion by, 541 .

Conversion of the obverse 241,305 , 541.

Copernican 118.

Creation-why creation does not imply a change in the nature of God 303, 679-680.

Crescas, Asher, 680.

Crescas, Hasdai,- - see Preface and contents of the Introduction at the beginning of the volume.

\section{D}

Dapiera, Solomon ben Immanuel, 459, 501.

Davidson, I., 567.

Definition-what it must contain 523, $575,660-661$; convertible with the definiendum 233, 526.

Delmedigo, Elijah, 589.

Democritus 411-412, 463. See also Atomists.

Demonstration-see Proof.

Dense - see Rare.

Descartes 97, 626, 654.

Desire 547.

Dialectic argument 326.

Didactic argument 326.

Diels, H., 356, 357, 401, 415, 445, 472, $526,548,581,582,635,646$.

Dieterici, F., 418, 421, 580, 635, 662.

Dimension 591. 
Diminution-see Growth.

Discrete-see Quantity.

Disposition-meaning of 688,690 .

Distance 591.

Divisibility-does not always imply composition $62-63,393 \mathrm{ff}$.; divisibility and changeability 80-81, $241 \mathrm{ff}$.

Division-logical 332.

Dozy, R.P.A., 421.

Drawing 562.

Dry and moist-as qualities 688 .

Duhem, P., 123, 586.

Duns Scotus, J., 97, 654.

Duran, Profiat,- - see Efodi.

Duration 654-658. See also Time.

\section{E}

Earth-moves absolutely downward $141,161,337,412$; is absolutely heavy 239, 412; spherical and at rest 451; called 'centre' 451, 454; what is the proper place of element earth 445-446, 456.

Edelmann, H., 586.

Efodi - natural elements move by themselves 675 .

Efros, I. I., 365, 471.

Elements - called 'simple bodies' 348; their upward and downward motion $141,161,337,412$; their weight and lightness 239, 412; their proper places 445-446; their relations to each other 450 ; whether or not they are moved by themselves 88-89, 670-673.

Elijah Delmedigo 589.

Elijah Habillo 589.

Empedocles 321.

Energy 526.

Entelechy-meaning of 526; 'first entelechy' 525.

Equal and unequal-not applicable to an infinite 423.

Eristic argument 396.

Essential order 481.

Eternal time $423 \mathrm{ff}$.

Eternity-identical with God 662.
Ether-in Aristotle 119; in modern physics as compared with Crescas' vacuum 117.

Euclid-see Index of Passages and also Pseudo-Euclid.

Eudemus 635.

Even and odd-see Number.

Extension - Hebrew, Arabic and Greek terms for 591; and matter 120 ; attribute of extension 122-123; possibility of an infinite incorporeal extension 62-63, 116-117.

Extremity 344.

\section{$\mathrm{F}$}

Faculties-in the sense of 'internal senses' 667.

Falaquera, Shem-țob ben JosephMoreh ha-Moreh may have been used by Crescas 22; definitions of motion 525; on the nature of the motion of the spheres 537 ; eternal motion of the spheres and time 646; spheres not composed of matter and form 595-596; change of substance in no-time 503. See also Index of Passages.

Falsehood-possible and impossible 149, 343; fictitious falsehood 195, 199, 343.

Farabi-see Alfarabi.

Fear-see Pleasure.

Figure-included under quality 307 , 686-688; Hebrew and Arabic terms for it 687 ; definition of 173,307 , 388 ; no body without it 307 ; divisibility of the geometric figure of a body 603; figure of a syllogism called 'force' 342 .

Fire-moves absolutely upward 141, $161,337,412,450$; has no weight 239,412 ; not similar to the element below it 450 ; transformable into air 450 .

First Mover-proof for its immovability 553-554; whether to be identified with God 462 ; not identified 
with God by Avicenna 110; not identified with God by Maimonides 106, 606; identified with God by Averroes 608; is a substance 575576.

Flensberg, H. J., 523, 611.

Force - the term as used by Maimonides 99, 259, 577; as the figure of a syllogism 342 ; infinite force in a finite body 105, $267 \mathrm{ff}$; distinction between a force infinite in time and a force infinite in intensity 106, 273, 612-614.

Form-accidental, corporeal, elemental, essential, first, natural, of corporeity, proper, specific 578 ; the two usages of the term form 573574 ; why form is a substance 103 , $104,259,573-576,601-602$; called accident by Kalam 570, 601-602; called 'force' by Maimonides 99, 257, 259, 577; constitutes existence of body $257 \mathrm{ff}$.; not identical with place 155,357 ; in what sense called limit 155, 358-359; cause of motion of elements $89,299,672-673$; change of form is in no-time 243, 544; corporeal form: its origin, history and meaning 100-101, 579-590; corporeal form and Ibn Gabirol's universal matter 598-601; indivisibility of corporeal form 104-105, 265,602 .

Forms, Platonic, 665.

Frederick II, Emperor, 34.

Friedlaender, I., 465.

Friedländer, M., 2.

Fundamentals 319 .

\section{G}

Galen 526, 567.

Galileo 127.

Gandz, S., 420.

General argument (or proof) 328, $390,462,542$.

General place 458 .

Freneration and corruption-change with respect to substance 229; not called motion $498 \mathrm{ff}$; in no-time 229, 503; there must be an instant of rest between them 277, 619; there need not be an instant of rest between them $281,626-627$; relative and absolute $283,514,519,628$, 631 ; are they preceded by locomotion and qualitative change? 281, 628 ; when generation is prior to all other motions 283,632 .

Genus-motion one in genus 615 .

Gershon ben Solomon of Arles-why air descends into a ditch 413; magnetic attraction 566, 567. See also Index of Passages.

Gersonides - his commentaries on Averroes used by Crescas 9-10, 365, $369,370,373$; why infinite body must be infinite in all dimensions 430; divisibility of number into even and odd 477 ; infinite number of concentric spheres 462; infinite number of causes 496 ; the place of the spheres and the universe 440 , outside the universe there is 'nothing' 115,421 ; eternal time 424; many worlds 472,475 ; definition of motion 528-529; original time of motion 406-408; why air descends into a ditch 412-413; magnetic attraction 566; the term centre as applied to the earth 454 ; time $652-$ 653; version of Aristotle's definition of time 638; active intellect 547; definition of continuous quantity 418; impenetrability of bodies 415 ; centre of the earth only a point 455. See also Index of Passages.

Ghazali-see Algazali.

Ginzberg, L., 319, 458, 535.

"Glory of the Lord"-history of the interpretation of the expression of 201, 459-462.

God-proofs for existence, unity and incorporeality of 323-324; immovable, unchangeable and indivisible 
247, 550; whether identified with the 'prime mover' $106,110,461-$ $462,606,608$; positive attributes of 13-14; attributes of extension and thought of 122-123; possibility of two deities 14; as the place of the world 123, 201; relation to the world in Aristotle, Crescas and Spinoza 122-123; why creation does not imply change in 303, 679-680.

Goldenthal, J., 397.

Goldziher, I., 461, 500.

Gracian-See Zerahiah ben Isaac.

Graetz, H., 17, n. 62.

"Grain of umstard seed" and "grain of millet" 342-343.

Gravity and levity-see Weight and lightness.

Great and small-terms applicable to continuous quantity $139,189,339$, 418; inapplicable to an infinite 423.

Great Captain-reference to trip to Naples and meeting Leo Hebraeus 600.

Grote, G., 326, 336.

Growth and diminution - change with respect to quantity 229; Hebrew and Arabic terms for 399; involves locomotion 231, 521. See also Motion.

Guttmann, Jakob, 365, 420, 639.

Guttmann, Julius, 36, n. 113, 347, 626.

\section{$\mathrm{H}$}

Haarbrücker, Th., 337.

Habillo, Elijah, 589.

Ha-Levi, Judah,- - see Judah ha-Levi. Hamilton, W., 541.

Hard and soft-included under quality 688 ; called primary qualities 688 .

Harkavy, A. A., 461.

Harris, J. Rendel, 460.

Heath, T.L., 465, 623.

Heaven-see Spheres.

Heavy and light-see Weight.

Heiberg, I, L., 455.

Hen-see Zerahia ben Isaac.
Hermes 321.

Hillel ben Samuel of Verona-his commentary on the twenty-five propositions 1, 2; may have been used by Crescas 22; motion and change not convertible terms 522; categories of motion 501; locomotion of quantitative motion imperceptible 521 ; what kind of accidental motion cannot be eternal 551ff.; substance has no definition 575 ; description of substance 575; whether substance of spheres is composed of matter and form 598; time 641 ; possibility and potentiality 692 ; two senses of the term potential 697. See also Index of Passages.

Hirschfeld, H., 459, 501.

Homogeneity in nature 118-120.

Horovitz, S., 355, 376.

Horten, M., 482, 485, 486, 489, 494, $495,583,589,597,687$.

Hot and cold-as qualities 688 .

Husik, I., 11, 355.

\section{I}

Ibn Aknin. See Joseph Ibn Aknin.

Ibn Alsaig - see Avempace.

Ibn Baddja-see Avempace.

Ibn Bajja-see Avempace.

Ibn Gabirol, Solomon,-paraphrase of Aristotle's definition of place 364; term for 'proper place' 356 ; action of the animal soul is in time 549 ; acquisition of knowledge by the rational soul is in no-time 548; seven kinds of quantity 420 ; relativity of the terms matter and form 579; his universal matter and Crescas' corporeal form 598, 599, 600, 601. See also Index of Passages.

Ibn Janah 335, 563.

Ibn Latif, Isaac,--his argument for and against a vacuum explained 471 ; motion of the spheres natural 
and not voluntary 538; ideality of time 662. See also Index of Passages.

Ibn Roshd-see Averroes.

Ibn Shem-ţob-the literary activity of the familty 31 .

Ibn Shem-țob, Isaac ben Shem-țob,his works 31, n. 90 ; his criticism of Crescas 31-32; no quantity can be incorporeal 395, 396; divisibility of number into odd and even 479; infinite must be infinite in all dimensions 431; why 'principles' must be known 428; meaning of statement that vacuum is cause of motion 398; body must be bounded by surfaces 425 ; the place of the spheres and the universe 440; why 'rest' is not included in the definition of time 650. See also Index of Passages.

Ibn Shem-ţob, Joseph ben Shem-ţob -on Crescas' unacquaintance with the Tahafut 16-17; suggests that Or Adonai was written after the Bitful 'Ikkere ha-Nozerim 16; on the obscurity of Crescas' style 29.

Ibn Shem-ţob, Shem-ţob,-opponent of philosophy 31 .

Ibn Shem-ţob, Shem-ţob ben Joseph ben Shem-tob,- -his criticism of Crescas 32-33; why number and magnitude are inseparable from body 394; why 'principles' must be known 427; defends Aristotle's rejection of the identification of place with interval 441 ; whether spheres are composed of matter and form 598; on the changeability and indivisibility of the intellect 549; Maimonides' view on the hylic intellect 607; whether the form of the elements is the cause of their motion 673, 675; referred to by Abravanel on corporeal form 589. See also Index of Passages.

Ibn Tibbon, Judah, 327.

Ibn Tibbon, Samuel, his translation of the Moreh 21 ; only a few propositions quoted by Crescas from his translation of the Moreh 23; Maimonides' letter to him unknown to Crescas 22. See also Index of Passages.

Ibn Tufail 584.

Ibn Zaddik-see Joseph Ibn Zaddik.

I bwan al-Safa-version of Aristotle's definition of place 362 ; place and vacuum 417-418; enumeration of discrete and continuous quantities 421 ; sixfold classification of motion 500; enumeration of various views on time 635 ; the definition of time as duration 655 . See also Index of Passages.

Imagination 211, 466, 546-547.

Immediate mover 699.

Immobility-distinguished from rest 646-649.

Impenetrability of flodies 187, 414416.

Impossible falsehood-see Falsehood. Inaliety 577 .

Incorporeal beings-how numbered 108-109, 293f., 666-667.

Increase-see Growth.

Induction 281, 628.

Inexistence-distinguished from 'admixture' 251, 265, 560 .

Infinite-general analysis of arguments against infinity 39 , n. 2 .

(1) impossibility of an incorporeal infinite magnitude 137, 329-335; Crescas' refutation $62-63,179$, 391-396; Altabrizi's afgument 149, 345-347; Crescas' refutation 63-64, 191, 423-424.

(2) impossibility of a corporeal infinite magnitude 151-157, 347-365; Crescas' refutation 41-43, 191-203, 424-462.

(3) impossibility of rectlinear motion in an infinite body 49-50, 157169, 365-379; Crescas' refutation 50-51, 203-205, 462-464.

(4) impossibility of circular motion 
in an infinite body $51,169-175$, 379-390; Crescas' refutation 51-53, 205-213, 464-470.

(5) general arguments against an infinite magnitude $175-177,390$; Crescas' refutation 215, 471.

(6) impossibility of an infinite number of magnitudes $65,219,476-477$; Crescas' refutation 219-221, 477479; the two kinds of infinite number $64-65,221,480-481$; infinite number of disembodied souls 15-16, 67-68, 223, 484-490, 493.

(7) impossibility of an infinite number of causes and effects $65-66,223$, 482-484; Crescas' refutation 66-69, 227, 490; Narboni's argument 227, 491-493; Crescas' refutation 66-67, 227-229, 493-496; Crescas' theory of the possibility of an infinite number of effects $67-69,229,496-$ 497.

(8) impossibility of an infinite force in a finite body 105-106, 267ff.; Crescas' refutation 271ff.; distinction between a force infinite in time and a force infinite in intensity 106 , $273,612-613$.

(9) the unknowability of the infinite 193,426-428,492; how an incorporeal infinite extension can be divisible and yet not be composite $62-63$, 391-396; meaning of the statement that no infinite can be greater than another infinite $63-64,191,423$ 424 ; indivisibility of infinite number into odd and even $221,223,478$, 488; possibility of an infinite number of concentric spheres and proper places $50-51,159,203,370-373$ 463 ; infinite essential causes and accidental causes 494ff.; infinite causes 'in a straight line' and 'according to kind' 495 ; infinite divisibility and addibility 464 .

Instant-not time 285; the present is an instant 285; time not composed of instants 277 ; common limit of past and future 624 ; infinite to finite like point to line and like instant to time 163 ; no motion in an instant $163,269,271$; there must be an instant of rest between opposite motions $275,277,618-622$; there need not be an instant of rest between opposite motions 281 , $623 \mathrm{ff}$.

Intellect-general sense of the term 604; hylic 606-607; acquired 486, 495,607 ; active 546,547 ; active intellect is a substance 575-576.

Intelligences-whether causally related to each other 108-109, 293295, 666-667; how they are numbered $i b i d . ;$ analogy of their relation to the spheres to the relation of intellect to body $605 \mathrm{ff}$.; called final cause of motion of spheres 605-606; called soul of the spheres 265-267, 607 ; whether they are moved accidentally while moving 606,608 ; are not in time 287; are in time 291; are substances $\mathbf{5 7 5 - 5 7 6 .}$

Ionian School 569, 570.

Isaac Abravanel-see Abravanel.

Isaac Arama-see Arama.

Isaac Israeli-sixfold classification of motion 500; why form is substance 574. See also Index of Passages.

Isaac Ibn Latif-see Ibn Latif.

Isaac ben Nathan-his translation of Altabrizi used by Crescas 21; his style 21 ; what kind of accidental motion cannot be eternal 551, 552; quoted by Narboni 552. See also Index of Passages under Altabrizi.

Isaac ben Shem-țob - see Ibn Shem-ţob, Isaac.

Israeli-see Isaac Israeli.

\section{$\mathrm{J}$}

Jedaiah Bedersi 2.

Joachim, H. H., 513. 
Joël, M., 11, 34, n. 102, 36, n. 113, 123, 321, 322, 335, 561.

Joseph ben Judah Ibn Aknin-deduction of the opposition of matter and form 592; corporeal form 585, 586, 587.

Joseph Albo-see Albo.

Joseph Caspi 323.

Joseph Zabara-magnetic attraction 567.

Joseph Ibn Zaddik-why the earth is stationary and called centre 452 ; the proper place of element earth 446, 456; corporeal form 588. See also Index of Passages.

Joseph, H. W. B., 335.

Joy 547.

Judah Abravanel-see Leo Hebraeus.

Judah al-Harizi 21, 324, 689.

Judah Ha-Levi-infinite number of causes and effects 492; implied Aristotelian definition of place 363 ; the place of the outermost sphere 441 ; motion of the spheres is natural motion 538; acquisition of knowledge is in no-time 548; meaning of the expression the "Glory of the Lord" 461. See also Index of Passages.

Judah Messer Leon 506.

Judah ben Simeon 663 .

\section{K}

Kalam-its atomistic theory 120 ; form only an accident 574, 601 .

Kalonymus ben David ben Todros 12 , n. 50.

Kalonymus bin Kalonymus 9.

Kaspi, Joseph, 323.

Kaufmann, D., 11, 365, 667.

Kimhi, David, 459. See also Index of Passages.

Kindi-See Alkindi.

Knowledge-originates in sense perception 546; acquisition of it is in no-time $247,547-548$,
$\mathrm{L}$

Lambert, M., 420, 461.

Landauer, S., 339, 378, 396, 472, 492, 597.

Leibnitz, G. W., 123, n. 27.

Leo Hebraeus-follows Crescas' view on prime matter 600 ; meeting with King of Spain and Great Captain 600.

Levias, C., 401.

Lightness-see Weight.

Limit - the different Greek words underlying the Hebrew and Arabic words for it 358-359; as applied to form 155, 357, 358-359; as applied to place 362,364 .

Line-definitions of 392-393 ; not composed of points 277 ; indivisible with respect to width 265,602 ; infinitely divisible 392 ; one of the continuous quantities 419.

Locke, J., 326, 654.

Löwy, M., 336, 401, 587, 590, 592.

Logical argument (or proof) 328, 390.

Lucretius-magnetic attraction 563.

\section{M}

Magnes, J. L., 587, 590, 592.

Magnet-Hebrew terms for 562-563; different theories of magnetic attraction 90-92, 255, 257, 563-564, 565-568; significance of Crescas' theory of magnetic attraction 121.

Magnitude - one of the continuous quantities $341,419,541$; infinitely divisible 464,541 ; but not infinitely addible 464 ; small and great but not much and few 337; measurable but not numerable 337,419 ; term used by Crescas to include line, surface, body and place 419 .

Maimonides - and Averroes 323; classification of philosophers 321; distinction between 'authors' and 'commentators' 322; Moreh written with great care $27-28$; the twenty- 
five proposition as a literary unit 1-2; method of commentators on Moreh 27; his letter to Samuel Ibn Tibbon unknown to Crescas 22; infinite number possible in immaterial beings $219,223,477$; infinity of disembodied souls 485 ; infinite number of magnitudes and infinite number of causes and effects $480 \mathrm{f}$; essential and accidental infinite causes 494; general and particular place 352 ; allusion to two theoris of a vacuum 401; matter, form and privation 572,700 ; transformation of fire into air 450; why the earth is stationary 452 ; his use of the term 'force' 99, 259, 577; when a simple cause can produce more than one effect 490; cause which acts by contact and cause which does not act by contact 562 ; magnetic attraction 563; the atomism of the Kalam 121, 570; his use of the terms change and motion 502-503; every change is in time 502 ; generation and destruction of forms is in no-time 504, 544; vague as to whether the elements are moved by themselves 674-675; spheres animate and intelligent beings 605-606; motion of the spheres is voluntary motion 535; spheres composed of matter and form 598; analogy between relation of the Intelligences to the spheres to the relation of soul to body 606ff.; Intelligences have accidental motion 606; the hylic intellect 606-607; the acquired intellect 607; immortality of the soul 295 ; immovability, unchangeability and indivisibility of God 550; God not identical with the 'first mover' 106, 606; possibility and potentiality 690-691; list of primary qualities 688 ; his versions of Aristotle's definition of time 636637 ; no time prior to creation 663 ; meaning of expression "Glory of the Lord" 460-461. See also Index of Passages.

Malter, H., 461.

Marginal notes on MSS. of the Or Adonai 29, n. 87, 326, 333-4, 338-9, 382, 684-5.

Marx, A., 10, n. 45.

Matter and form-pre-Aristotelian views 569-570; Aristotelian method of deducing the opposition of matter and form 99-100, 307, 571-572, 594, 686, 699; Avicennian method of deducing the opposition of matter and form 101-102; 591-594, 686; list of adjectives qualifying the terms matter and form 567-568; 'second matter' 580; relativity of matter 578-579; why matter is substance 573 ; matter not identical with place 357 ; potentiality of matter $112-113,576$; matter recognizable only in thought 591 ; divisibility of matter 105, 265, 602; Crescas' theory of matter and form 104, 113, 120-121, 263, 598-602; whether the substance of the spheres is composed of matter and form 103-104, 119, 120, 261, 594-598. See also Form.

Measure - in the definition of time 289, 660 .

Medium — of motion 185, 409-411.

Messer, Leon, 506.

Mixture-see Inexistence.

Modern 320-321.

Moist-see Dry.

Momentum 337.

Moscato, Judah Aryeh, 538.

Moses ha-Lavi 483.

Moses ben Joshua of Narbonne-see Narboni.

Moses ben Tobi-see Abu 'Imran.

Motion and change-difference between change and motion 74-75, 233, 463, 498, 522; but Maimonides: all changes are motions 503 ; distinc- 
tion between change in time and in no-time or gradual and sudden change $71,229,232,498,503-504$, 543-544, 616; but Alexander and Maimonides: every change is in time 243, 502, 543; generation and destruction of forms is in no-time $243,503-504,544$; generation and corruption in substance is in notime 503 ; terminations of the processes of change and motion are in no-time 243 ; activity of the intellect in acquiring knowledge is in no-time $247,547-548$; motion in no-time is impossible 145,147 ; no motion in an instant $163,269,271$; the motions of pleasure and pain are in time 247 , 548-549; change in quality is in time 243,504 ; change in quality is in no-time 205; change in quality takes place all at once 464 ; change in quality may be sudden 464 ; locomotion is gradual 464 ; the necessity of a medium for motion 185 , 403ff., 463; the impossibility of motion in a vacuum $141 \mathrm{ff}$.; possibility of motion in a vacuum 183 , 402; the 'sustaining subject' and the 'material subject' of motion $72-74,231,233,507-520$; the definitions of motion $75,233,235$, $511,523-530$; the continuity of motion $341,273 \mathrm{ff}$., $615 \mathrm{ff}$; the five things involved in motion 511ff.; no absolute beginning of motion 467; motion named after terminus ad quem 518; how motion is called one $82-83,273,615-616$; the classification of motion into natural, violent, essential, accidental and participative 76-77, 79-80, 235-239, 531-540; to be moved essentially or accidentally with the whole 443; no accidental or violent motion can be eternal 81 , 249, 551-555; qualifications of this proposition $82,249-253,555-561$; the categories of motion 70-71, 229-233, 498-503; whether there is motion in all the ten categories 504 ; why not in all the categories 73-4; in the categories of action and passion 231, 233, 506; in the category of passion 513, 517; in the category of relation 506; in the category of position 231, 439, 502, 504-506; the four categories of motion 229; locomotion is called motion proper 229, 231, change in substance is consequent upon all the other motions 231, 520; whether motion of growth involves locomotion 74 , $231,520-521$; the order of priority of the four categories of motion 87-88, 281-283, 627-628, 632; explanations of upward motion 78-79, $141,185,239,410-412$; opposite motions cannot be continuous 83-84, 273-279, 615ff.; opposite motions can be continuous $84-87,279-281$, $623 \mathrm{ff}$.; circular motion is motion in position 403, 439, 505-506; circular motion does not require spherical body 213,470 ; continuity and eternity of circular motion 86-87, 273, $279,281 f ., 623,630$; whether the circular motion of the spheres is natural or voluntary $15,77-78,106-$ $107,118,119-120,237,273,535-$ 538 ; motion requires a cause 88,297 , $668 \mathrm{ff}$; f final and efficient cause of motion 90, 253, 561f.; four ways of producing motion 562 ; efficient cause is moved while moving 90, 253; cause of motion either external or internal 88, 297, 678; soul cause of motion in animals 297, 669; what the cause of the natural motion of the elements is $88-89,141,297-$ $299,337-338,670-675$; theory of an original time of motion 57, 183-185, $205,271,403-410$; cause of the difference of speed of motion 143 , 340. 
Much and few-applied to continuous quantity 418; inapplicable to an infinite 423.

Müller, M. J., 364, 422.

Multitude - opposed to magnitude 419.

Munk, S., 352, 480, 553, 562, 571, 577, $680,687,700$.

\section{$\mathrm{N}$}

Narboni, Moses,-his works used by Crescas 11, 21-22; why infinite magnitude must be infinite in all dimensions 429; incorporeal infinite surface 424 ; divisibility of infinite number into odd and even 478-479; infinite number of causes and effects 492; version of Aristotle's definition of place 362; on Algazali's and Aristotle's definitions of place 363; the place of the spheres and of the universe 437; vacuum 400, 401; impenetrability of bodies 416 ; why 'principles' must be known 426; definitions of motion 510,511 ; the two subjects of motion 507-510, 697 ; motion and change not interchangeable 522 ; change in the category of passion 513,517 ; accidental and participative motion 534 ; definition of nature 672 ; change in substance is in no-time 503; what accidental motion cannot be eternal 551,559 ; the causes of motion 561; corporeal form 583f., 585, 586, 589; versions of Aristotle's definition of time 636, 637; possibility 683; two senses of the term possible 697; Maimonides' view on the hylic intellect 606; Platonic Ideas 665. See also Index of Passages.

Natural order 481.

Nature cause of the motion of the elements 299, 672-673; called a form 299; Hebrew versions of Aristotle's definition of 672 .

Necessary-see Possibility.
Necessary per se 110-111, 662.

Neumark, D., 319.

Newton, Sir Isaac, 126.

Nissim ben Reuben 539.

Nothing 115.

Number-one of the discrete quantities 419f.; infinitely addible but not infinitely divisible 464 ; divisible in to odd and even 219,477; whether infinite number is divisible into odd and even 221, 478f.; distinguished from measure $289,419,660$; the sense in which it is used in the definition of time $289,637,658-660$.

\section{$\mathrm{O}$}

Occam, William of, 97, 654.

Odd and even-see Number.

Odor-see Taste.

Oral transmission of Jewish philosophy to Christians 34-35.

Order in nature $221,225,481$.

Order in position 221, 225, 481 .

Original time of motion-see Avempace and Motion.

\section{$\mathrm{P}$}

Pain-see Pleasure.

Palquera-see Falaquera.

Particular proof 462, 549.

Passion, category of,- - see Action and Motion.

Perseity 577.

Persuasive argument 397.

Petitio principii 335-336.

Philo-meaning of $\mathrm{the}$ expression "Glory of the Lord" 460; God as the place of the world 123 .

Phinehas ben Meshullam 322.

Pico della Mirandola, Giovanni Francesco,- - his references to Crescas 34 . See also Index of Passages.

Pilpul, the logic of Talmudic, 24-29.

Pinsker, S., 420.

Place - one of the continuous quantities 419; Aristotle's discussion of place $44-45,153-157,354-365$; va- 
rious Arabic and Hebrew versions of Aristotle's definition of place 157, 362-365 ; Crescas' refutation of Aristotle's definition of place 46-48, 195-203, 431-462; different interpretations of Aristotle's conception as to the place of the spheres and the universe $45-47,115,195,432-$ 441 ; Crescas' identification of place with vacuum $195,441-443$; Crescas' definition of place 48-49, 199, 458; particular and general place 352 ; place and space 116, 352; 'first,' 'proper' and 'common' place 356, 458 ; the proper places of the four elements $45,445-446,602$; the proper place of earth 445-446; proper place as a final cause of the motion of the elements 338; possibility of an infinite number of proper places 50-51, 373, 462; Crescas' denial of proper places 79,456 ; the argument from place against an infinite magnitude 43-44; the definition of place used as an argument against an infinite magnitude 43-44, 354-355; the expression that God is the place of the world 201, 123-124. Plato-infinity 330, 395; place 356 , 357; weight and upward motion 411-412; denial of distinction of above and below 463; time 635 , 639; time image of eternity 662 ; Ideas 665 ; said to be source of Avicenna's view as to composition of the substance of the spheres 597.

Pleasure and fear-called either 'qualities' or 'motions' of the soul 548; take place in time $247,548-549$.

Plotinus-his classification of the various views on time 635,640 ; analysis of his own view on time $654-655,96-97$; time the image of eternity 662 ; eternity identical with God 662; 'magnitude' or 'corporeal form' 582. See also Index of Passages.
Plutarch-place 363; vacuum 400, 417, weight and lightness 411 ; body 588; time 639. See also Index of Passages.

Point-indivisible 265, 602; motion of a point $239,538-539,546$. See also Line.

Porphyry 321.

Position-definition of 307, 689-690; as na inseparable accident 307 ; as a separable accident 690 ; 'relation in position' 689 ; 'a certain position of parts' 688; motion in the category of position $231,439,502,504-506$, 535.

Possibility and necessity-Aristotle's view 109-110, 681; Avicenna's view 110-111, 303, 305, 680-685; Aver. roes' view $111,680-681$; may be applied to an existent or to a nonexistent subject $113,313,697-698$; the accidental is only possible 82 , 249,551 ; the possible cannot be conceived as not becoming realized in infinite time $82,249,551$.

Potentiality-distinguished from possibility $112,690-693$; the potential as non-existent 113, 309-313, 690ff.; the potential as material 113,313 , 696ff.; passing from potentiality to actuality 89-90, 299-303, 676ff.

Probabilities 319.

Prime Mover-see First Mover.

Prior 629.

Privation 421, 683, 700.

Projectile 339.

Proof-classification of the various types of proofs $325-6,328,390$, 462, 542.

Proper places-Aristotie's theory of 45, 445-446.

Proposition-must not be tautological 309-311, 693.

Pseudo-Aristotle's Theology 662-see also Index of Passages.

Pseudo-Bahya - sixfold classification 
of motion 500; meaning of expression "Glory of the Lord" 461.

Pseudo-Euclid's work on Weight and Lightness 457.

Ptolemaic 118.

Pushing 562.

Pythagoras and Pythagoreans-their philosophy called antiquated by Maimonides 321; infinite 330, 395, 400-401, 403; vacuum 54, 344, 400, 414 ; time 635 .

\section{Q}

Quality-list of qualities 687-688; 'qualities of the soul' 548; change in the category of quality, see Motion and Alteration.

Quantity - continuous and discrete 289, 419; definition of continuous quantity 418-419; enumeration of quantities 189, 419-421; divided into magnitudes and multitudes 419 , 337 ; an inseparable accident 307 ; in the sense of corporeal form 578; change in the category of quantity, see Motion and Growth.

Quantum-in-general 633.

Quirós Rodríguez, C., 482, 589.

Quod erat demonstrandum 339.

\section{$\mathbf{R}$}

Rare and dense-as qualities 688 ; as corporeal affections 687-688; as 'a certain position of parts' 688; as primary qualities 688 .

Rabinowitz, S. P., 461.

Rawidowitz, S., 465.

Reason 125.

Rehman, M. J., 422.

Relation-definition of 689-690; 'relation in position' 689; change in the category of relation, see Motion.

Rest-distinguished from immobility 646-649; how it measures time 287289, 646-651.

Rhetorical argument 397.

Rolling 562.
Roots $131,319$.

Ross, W. D., 328, 578.

Rough and smooth-as corporeal affections 687-688; as qualities 688 ; as primary qualities 688 ; as 'a certain position of parts' 688 .

\section{S}

Saadia - infinite cannot be known 492; impossibility of an infinite number of causes 492 ; definition of place 364-365; sixfold division of motion 500 ; motion of the spheres is natural motion 538; time 638-639, 640, $655-656$; sevenfold division of quantity 420; impossibility of many worlds 472 ; meaning of the expression "Glory of the Lord" 461. See also Index of Passages.

Samuel ha-Nagid 491.

Samuel Ibn Tibbon-see Ibn Tibbon. Saul ha-Kohen Ashkenazi 589.

Schenkl, H., 437, 544.

Schwegler, A., 328.

Scriptural Beliefs 131, 319.

Sefirot $459 \mathrm{ff}$.

Sense-perception 546.

Senses 667.

Shahrastani-classification of Greek philosophers 321 ; infinite magnitude 347 ; infinite number of disembodied souls 486 ; categories of motion 507 ; no motion in the category of substance 502 ; motion in position 505 ; change in substance is in no-time 503; deduction of the opposition of matter and form 591; corporeal form 583. See also Index of Passages.

Shalom, Abraham, - see Abraham Shalom.

Shebil ha-Emunah 538.

Simple bodies 348 .

Simplicius-see Index of Passages.

Small and great-applied to continuous quantity $138,181,337,418$.

Smooth-see Rough. 
Sophists 321 .

Soul-general sense of the term 604; as a substance 575-576; indivisible 247,549 ; immortality of the soul $295,488,667$; 'souls and intellects' 323, 486, 604-605, 668; 'motions' and 'qualities' of the soul 548; infinite number of disembodied souls 15-16, 67-68, 109, 223, 484-490, 493; cause of motion in animals 297 , 669; efficient cause of the motion of the spheres 605-606; relation of the soul of the sphere to the sphere 251 ; the soul of the sphere has accidental motion 251; sphere has no soul 607 ; Intelligences called souls of the spheres 265-267, 607; relation of soul to body 251,560 ; time exists in the soul 289, 661-662, 98.

Space-see Place.

Spain, King of,-reference to trip to Naples and meeting Leo Hebraeus 600.

Speech-discrete quantity 419, 421.

Spheres, celestial,-whether composed of matter and form 103-104, 119, 261, 594-598; the nature of the circular motion of the spheres 15 , 77-78, 106-107, 118, 119-120, 237, 273, 535-538; soul and Intelligences of the spheres 265-267, 605-612; the place of the spheres $45-47,115$, 195-199, 432-441; 'parts of the spheres' 251, 256; not subject to corruption 614 ; devoid of qualities 273,614 ; not heavy or light 195 , 614. See also Motion, Intelligences, Soul.

Spinoza, B., 36-37, 97, 120, 377, 394, $423,466,654$.

Steinschneider, M., 2, n. 3; 10, n. 44; 12 , n. 49 , n. $50 ; 19 ; 19$, n. $66 ; 457$; $526 ; 601$.

Stoics 356.

Straton Lampsacenus 471.

Suarez, Fr., 97, 654.
Subject-distinguished from 'abode' 577; the 'sustaining' and the 'material' subject of motion 72-74, 231, $233,507-520$.

Substance-has no true definition 575 ; its characteristics 102-103, 574-576, 640,662 ; classification and enumeration of substances 572-576; 'individual,' 'universal,' 'primary,' 'secondary' 699, 667; motion in the category of substance $70,229,231$, 503,520 ; whether substance of the spheres is composed of matter and form, see Spheres.

Substratum-see Subject.

Surface-one of the continuous quantities 419; not composed of lines 277 ; how divisible 265, 602; introduced into Aristotle's definition of place 362,364 .

Syllable -discrete quantity 421 .

\section{$\mathrm{T}$}

Tabrizi-see Altabrizi.

Taste and odor 688 .

Taylor, Th., 356, 357, 415, 445, 455, $472,526,548,581,635,646$.

Text - (1) conjectural emendations adopted 158 (374, n. 104); 160 (375, n. 106$) ; 172(387$, n. 143$) ; 194(431$, n. 50$) ; 210(466$, n. 113$) ; 210(467$, n. 114); $212(470$, n. 121$) ; 266$ $(611$, n. 6). (2) conjectural emendations suggested 469 , n. $120 ; 564$, n. 8. (3) variant readings discussed 379 , n. $122 ; 423$, n. $37 ; 446$, n. 65 ; $522-523$, n. $4 ; 568$, n. $11 ; 696$, n. 3 ; 697-698, n. 5.

Themistius - cited by Crescas 5; known to Crescas through Averroes 9; placed before Alexander by Shahrastani and Crescas 321; placed after Alexander by Maimonides 322 ; classification of arguments into demonstrative, eristic and rhetorical 396; infinite causes and effects 492 ; the place of the spheres and the 
universe $45,46,433,437,443,449$; the spheres not composed of matter and form 595, 596, 597; some changes are in no-time 243,543 , 544 ; immortality of the soul 667. See also Index of Passages.

Theophrastus 542, 635.

Thomas Aquinas 578 .

Time one of the continuous quantities $341,419,660$; not composed of instants 277; classification of preAristotelian theories of time in Arabic and Jewish philosophy 634636; Aristotle's arguments for his definition of time 94-95, 285, 640644 ; various versions of Aristotle's definition of time in Arabic and Jewish philosophy 636-640; implications of Aristotle's definition of time 95-96, 287; Crescas' criticism of Aristotle's definition 287-291, 646ff.; analysis of Plotinus' definition of time and its traces in Arabic and Jewish philosophy 96-97, 654658; Crescas' definition of time 97-98, 289, 651-658; implications of Crescas' definition 98, 289-291; comparison of time to flowing water 641 ; meaning of 'to be in time' 287 , 644-646; the use of 'number' and 'measure' in Aristotle's definition of time 93, 289, 637, 658-660; time is the measure of motion and is measured by motion 646-647, 655; whether time is also the measure of rest $93,287,647-651$; whether time is real or ideal $96,98,289,661-662$; eternal and immovable beings not in time 96, 98, 287, 645-646, 662; whether time existed prior to creation 96, 98, 291, 663-664; time the image of eternity 662 ; why Altabrizi described time as having necessary existence 662 ; theory of original time of motion 57, 183-185, 205, 271, 403-410.

Tradition 125, 319-320.
True Opinions 319.

Truth-Aristotle's definition of 324, 456-457.

Tufail-see Ibn Tufail.

\section{$\mathrm{U}$}

Unity of God 14, 324.

Universal matter 599, 600, 601.

Universals 107-108, 664-666.

Universe-finite or infinite 115-118; whether homogeneous and continuous or not 118-120.

\section{V}

Vacuum-different theories of 54,343 344 , 400; arguments against the existence of a vacuum 139ff., 337 345,471 ; Crescas' refutation 54-60, 181-189, 398-422; arguments for the existence of a vacuum 181,398 , $60-62,189,417-422,471$; nature's abhorrence of a vacuum 115,413 ; identification of vacuum with place 356-357, 417, 441; significance of Crescas' infinite vacuum 116-117; Crescas' infinite vacuum and universal ether 117 .

Versor, Joannes, 626, 660.

Vision-impossible in a vacuum 471 . Void-see Vacuum.

\section{W}

Water-has relative motion upward $141,161,337,412$; is relatively heavy and light 239, 412 ; its relation to fire 450 .

Waxman, M., 36, n. 113.

Weight and lightness-theories of 58-59, 78-79, 337-338, 410-411; of the elements 239,412 ; absolute and relative 239; the spheres are neither heavy nor light 195, 614; denial of absolute lightness 59, 78-79, 126, $185,239,411,539$; called 'affections' 688; called 'corporeal affections' 687-688; called 'qualities' 688.

Wolfsohn, Julius, $12 \mathrm{ff}$. 
Wolfson, H. A., $14 ; 31$, n. $90 ; 37$, n. $115 ; 97 ; 687$.

World-its threefold division 201,459; Aristotle and Crescas on the possibility of many worlds 117-118, 217, 472-476; creation or eternity of the world 96, 98, 191, 211, 283, 424, 632, 664,679 ; future destructibility of the world 424 .

Y

Yellin, D., 491.

\section{Z}

Zabara, Joseph,- - magnetic attraction 567.

Zeller, E., 320, 356, 411, 412, 506, 507, 526, 563, 686.

Zeno 639, 344.

Zerahiah ben Isaac ben Shealtiel Gracian (Hen) 2, 9, 396, 399.

Zerahia ha-Levy ben Isaac Saladin 12 , n. $49 ; 18$. 